\title{
ALTERNATIVE PSS BUSINESS MODELS OF ESCO: TOWARDS AN INNOVATIVE NEW MODEL
}

\author{
Eka Sudarmaji ${ }^{*}{ }^{1}$, Noer Azam Achsani*), Yandra Arkeman ${ }^{* * *}$, Idqan Fahmi**) \\ "University of Pancasila \\ Jl. Raya Lenteng Agung No.56-80, North Jakarta Selatan, Jakarta 12640, Indonesia \\ ${ }^{* *}$ School of Business, IPB University \\ Jl. Raya Pajajaran, Bogor 16151, Indonesia \\ ${ }^{* * *}$ Department of Agroindustrial Technology, Faculty of Agricultural Engineering and Technology, IPB University \\ Fateta Building Floor 2, IPB Darmaga Campus, Bogor 16680, Indonesia
}

\begin{abstract}
Product System Service (PSS) was an excellent way to create new customer value under hyper-competition. Both product and service components were not used individually but in integrating product, service, and system and their valid combinations. This paper investigated the case study and was performed between June 2019 and April 2020. The is study aims to explore the introduction of the study's purpose of exploring the company was introducing the latest PSS model in its own "Energy Saving Company (ESCO) model" with its capitals in Indonesia. This new business model was able to tap potential business opportunities in the energy-saving industry. The study used these three methods - Soft System Methodology (SSM), General Morphological Analysis (GMA) \& Business Model Canvas (BMC). In this paper, the authors performed SSM to reduce the gap that exists in the real world. GMA and BMC as other tools to ensure collaboration to form the new business model. The result showed that through PSS, the company could develop their own "ESCO model" under Energy Saving Agreement (ESA) or Energy Saving Performance Contract (ESPC), which was known as "saving back arrangement financing." By adopting PSS, the company could gain a competitive advantage since there was increasing demand for energy and limited supply in Indonesia; hence there was a vast, untapped opportunity in the energy-saving industry.
\end{abstract}

Keywords: BMC, Case study, ESCO, Morphological, PSS, SSM

Abstrak: Product System Service (PSS) adalah cara terbaik untuk menciptakan nilai pelanggan baru di bawah kompetisi bisnis. Didalam PSS, komponen produk dan layanan tidak digunakan secara individual tetapi didalam satu integrasi secara keseluruhan berupa kombinasi produk, layanan, dan sistem yang valid. Penelitian ini menyelidiki fenomena bisnis (kasus bisnis) di Indonesia. Penelitian studi kasus ini dilakukan antara bulan June 2019 dan April 2020. Tujuan penelitian untuk mengeksplorasi perusahaan yang akan memperkenalkan model PSS terbaru dalam model "Energy Saving Company (ESCO)" di Indonesia. Model bisnis baru ini mampu menangkap peluang bisnis potensial di industri efisiensi energi. Penelitian ini menggunakan ketiga metode - Soft System Methodology (SSM), General Morphological Analysis (GMA) \& Business Model Canvas (BMC). Untuk mengurangi kesenjangan yang ada antara dunia nyata dengan konsep bisnis yang berlaku, penulis mengunakan metode SSM. Sementara itu, GMA dan BMC digunakan sebagai alat lain untuk memastikan kolaborasi bagaimana mendapatkan konsep model bisnis baru. Hasil penelitian menunjukkan bahwa melalui PSS, perusahaan dapat membentuk model bisnis "ESCO" di bawah mekanisme Energy Saving Agreement (ESA) atau Energy Saving Performance Contract (ESPC), yang dikenal sebagai "saving back arrangement financing." Dengan mengadopsi PSS, perusahaan bisa mendapatkan keunggulan kompetitif karena adanya peningkatan permintaan energi dan keterbatasan pasokan di Indonesia; oleh karena adanya peluang yang luas dan belum dimanfaatkan untuk industri penghematan energi.

Kata kunci: BMC, Case study, ESCO, Morphological, PSS, SSM

\footnotetext{
${ }^{1}$ Corresponding author:

Email: esudarmaji@univpancasila.ac.id
} 


\section{INTRODUCTION}

This paper was motivated by the absence of companies that make breakthroughs in utilizing the energy-saving industry's potential in Indonesia. It was found that the lack of economic and financial incentives and limited financing options might be the most prominent problem of the promotion of energy efficiency at the current stage. With energy efficiency, Indonesia would gain many benefits such as increasing competitiveness, opening jobs, improving energy security, and reducing energy demand. It can reduce the need for coal-fired power plant construction and help facilitate electricity access targets for people who were not yet electrified. There is room to improve energy efficiency by strengthening compliance through the establishment of an ESCO.

Therefore, the government needs to help new ESCO enter the energy efficiency industry. Policies to provide incentives for projects in the energy efficiency sectors are doable at the macro, meso, and micro levels. The incentives program is instrumental in overcoming the energy gap and increasing the number of prospect companies as well as ESCO enter the program. On the other hand, Indonesia's current ESCO business model is not ready to tap the opportunity in the energy efficiency business sector. In the circumstances, the company's current business model is evolving rapidly and is focused on services (service enablers). Not all companies successfully build their business on the product-service model or Product Service System (PSS); thus, this model may not suit all companies. The change process requires fundamental changes in structure, culture, company competence, operations, and partnerships (Baines et al. 2009; Pawar et al. 2009). Companies that successfully ran the service change process would undoubtedly provide a better foothold in the market.

Product/Service-Systems (PSS) is a rapidly expanding research and industry practice area, especially in the last three decades, Ronja et al. (2017). This paper was in line with the number of companies concerned with energysaving, while the absence of energy-saving companies can overcome it. The PSS business model's use comes with the number of companies to sell their products bundled with services as a result-based revenue stream. Initially, the result-based compensation was derived from performance-based contracting of public-private partnerships (PPPs) in the mid-twentieth century. Over time, it evolves and found its way. BASF Coatings was the first company to use the 'cost per product' revenue stream since the late 1990s. Xerox, an American maker of printers and photocopiers, was providing resultsbased payments. It evolved once again as Roll Royce implements this model; the program's name was Power by Meter. When Roll Royce sells the machineand delivers a complex maintenance contract, they implement Power by Meter. Nowadays, many companies take a slightly different name, and there were substantial empirical studies on it.

The first research paper introducing a PSS was an article on Servitization by Vandermerwe and Rada (1988). Unfortunately, the first formal definition of PSS was given in Goedkoop, Van Halen, Te Riele, and Rommens (1999). Since then, most researchers have adopted this definition and have generally interpreted PSS as 'products and services incorporated in the system to provide the required user capabilities to reduce carbon. Goedkoop et al. (1999) added further clarity by defining the critical elements of PSS, namely as follows: 1) Products: tangible commodities produced for sale, 2) Services: activities (work) carried out for other people with economic value and often carried out commercially, and 3) System: a collection of elements, including their relationship. Several other definitions of the PSS concept were found in previous literature research i,e. User-oriented PSS, Result-oriented PSS, and Service-oriented.

The sustainability of this study of the PSS was consistent with empirical studies' results. PSS contributes to market growth by increasing the value-added felt by customers. PSS promotes improved efficiency and consistency through advanced technologies, customer focus, and special offers. Companies that use the PSS business model receive increased revenue and profit margins while also getting a more stable income than the product (Abdullah et al. 2010). On the other hand, customer loyalty and brand image have also increased where companies have developed deeper customercentric relationships in exploring new sales sources and new connections (Sakao and Lindahl, 2009).

This paper provided an initial model for developing the Soft System Methodology (SSM) to transform the Product Service System (PSS) business model in Indonesia's Energy Efficiency industry. One of the most potent reasons companies switch to PSS was the possibility of new revenue streams and the emergence of a unique customer value proposition. PSS was often interpreted as gaining closer relationships with 
customers and improving operational performance to a level that cannot be achieved only by hardware improvements. The difference between products and services, tangible and intangible, was very biased in supporting the translation, especially in terms of the strategies adopted to be more customer-oriented. The concept of the PSS can dissolve the boundaries between products and services. It can be used as a general framework that enables a managerial and organizational shift from selling products to providing unique and positive experiences with customized and resultsoriented solutions. The most appropriate revenue stream in the energy efficiency industry is the PSS business model that applies the business model as usage-oriented and result-oriented. Revenue streams are generated using specific services (Table 1).

This paper would investigate ESCO's current strategy to gain opportunities and open new markets with the explanation above. New opportunities that ESCO can do were to offer a PSS business model in the form of Energy Saving Agreement (ESA) or Energy Saving Performance Contract (ESPC), which was known as the "retrofit" agreement contract. Hence, the purpose of this study was to investigate ESCO's confidence in order to tap potential business opportunities in the energy efficiency industry under the new PSS business model.

Table 1. Classification of PSS characteristics

\begin{tabular}{|c|c|c|c|}
\hline $\begin{array}{l}\text { Three types of PSS } \\
\text { according to each } \\
\text { business model element }\end{array}$ & $\begin{array}{l}\text { Product-Oriented Services } \\
\text { (POS) }\end{array}$ & Use-Oriented Services (UOS) & Result-Oriented Services (ROS) \\
\hline Type of ESCO & $\begin{array}{l}\text { Traditional (outright) } \\
\text { purchase }\end{array}$ & $\begin{array}{l}\text { Energy Service Performance } \\
\text { Contract }\end{array}$ & Energy Saving Agreement \\
\hline Customer segments & $\begin{array}{l}\text { Clients who want or need } \\
\text { to have investments }\end{array}$ & $\begin{array}{l}\text { The ownership of the product } \\
\text { not to be the owner of the } \\
\text { product }\end{array}$ & $\begin{array}{l}\text { Clients who prefer not to own } \\
\text { physical products }\end{array}$ \\
\hline Value Propositions & $\begin{array}{l}\text { Product is the core of the } \\
\text { system, and clients have } \\
\text { their ownership }\end{array}$ & $\begin{array}{l}\text { ESCO delivers the functional } \\
\text { capability to the customer. The } \\
\text { customer access to a product }\end{array}$ & ESCO deliver of functional result \\
\hline Channels & $\begin{array}{l}\text { Indirect interface with the } \\
\text { end client }\end{array}$ & A lease contract & $\begin{array}{l}\text { Direct interface with the end } \\
\text { client }\end{array}$ \\
\hline Customer Relationships & Transactional based & $\begin{array}{l}\text { Blend of transitional and } \\
\text { relationship }\end{array}$ & Relationship-based \\
\hline Revenue Streams & $\begin{array}{l}\text { Payment in the form of the } \\
\text { sales price }\end{array}$ & $\begin{array}{l}\text { Payment is based on } \\
\text { availability }\end{array}$ & $\begin{array}{l}\text { Payment is based on per unit time } \\
\text { or unit use }\end{array}$ \\
\hline Key Partnerships & $\begin{array}{l}\text { Outsourcing of services. } \\
\text { Primary information } \\
\text { exchange with the partners }\end{array}$ & $\begin{array}{l}\text { Long-term collaboration with } \\
\text { service suppliers }\end{array}$ & $\begin{array}{l}\text { Need to organize outsourced } \\
\text { tasks efficiently }\end{array}$ \\
\hline Key Activities & $\begin{array}{l}\text { Large production } \\
\text { department/machinery }\end{array}$ & $\begin{array}{l}\text { Need fo new provider activities } \\
\text { and manage services }\end{array}$ & $\begin{array}{l}\text { New activities related to how } \\
\text { to design products and services } \\
\text { according to the function } \\
\text { required and how to extract } \\
\text { customer requirements }\end{array}$ \\
\hline Cost Structure & $\begin{array}{l}\text { Traditional production } \\
\text { costs }\end{array}$ & The need for capital is high & $\begin{array}{l}\text { Risk premium (responsibility or } \\
\text { total cots risks). There is a need } \\
\text { to determine all lifecycle costs. }\end{array}$ \\
\hline
\end{tabular}




\section{METHODS}

This paper investigates contemporary phenomena (case) in the real business world. The ESCO provider was 'MWS,' and the authors used a pseudonymous name for this study. MWS was intended to introduce the latest PSS model in their own "ESCO model" with their capitals in Indonesia. Hence, the interviewing process gathers information directly from the company's director, chief leaders, and general managers involved in the process. Interviews lasted anywhere from twenty minutes to sixty minutes and were performed between June 2019 and January 2020.

This paper would use Checkland's Soft Systems Methodology (SSM) to illustrate current practices on how an ESCO's company changed the energy-saving market structure by introducing a new PSS business model innovation Figure 1. The changes happened due to new technological, innovative services, supply chain management, optimized cost structures, and unique resources. Such a shift in corporate development was known by deliberately producing business model ideas based on the morphological thought process.

The authors developed a conceptual-based system for supporting a new PSS business model creation based on a single business case (case study). This alternative conceptual-based PSS business model creation examined and identified how PSS differed from the traditional business model. This sort of New Product-asa-Service system was a business model that historically sold the products to consumers. This paper would focus on GMA to find appropriate revenue streams, value, and risk distribution to structure the problem in ESCOs.

In the end, this paper adopted business model patterns. It used nine blocks of Osterwalder and Pigneur's (2010) because it provided a concise business model complete with financial, customer, and infrastructure aspects. The BMC could be an analytical tool on 'how an ESCO could create corporate value' (Figure 2). Through BMC, an ESCO could see how they could run their business, be involved in the production process, marketing, and other departments, maintain their relationships with customers to maintain its sustainability. The advantages of BMC were for strategic planning and development, a tool for expressing ideas, tools for knowing customers, as a dashboard/indicator, a tool to find out competitors (such as the level of competition). Besides all that, BMC could also analyze business portfolio models; innovation planning; to align the organizational mindset. Throughout the literature of the past decade, it has been possible to find several processes to make business models and reference models.

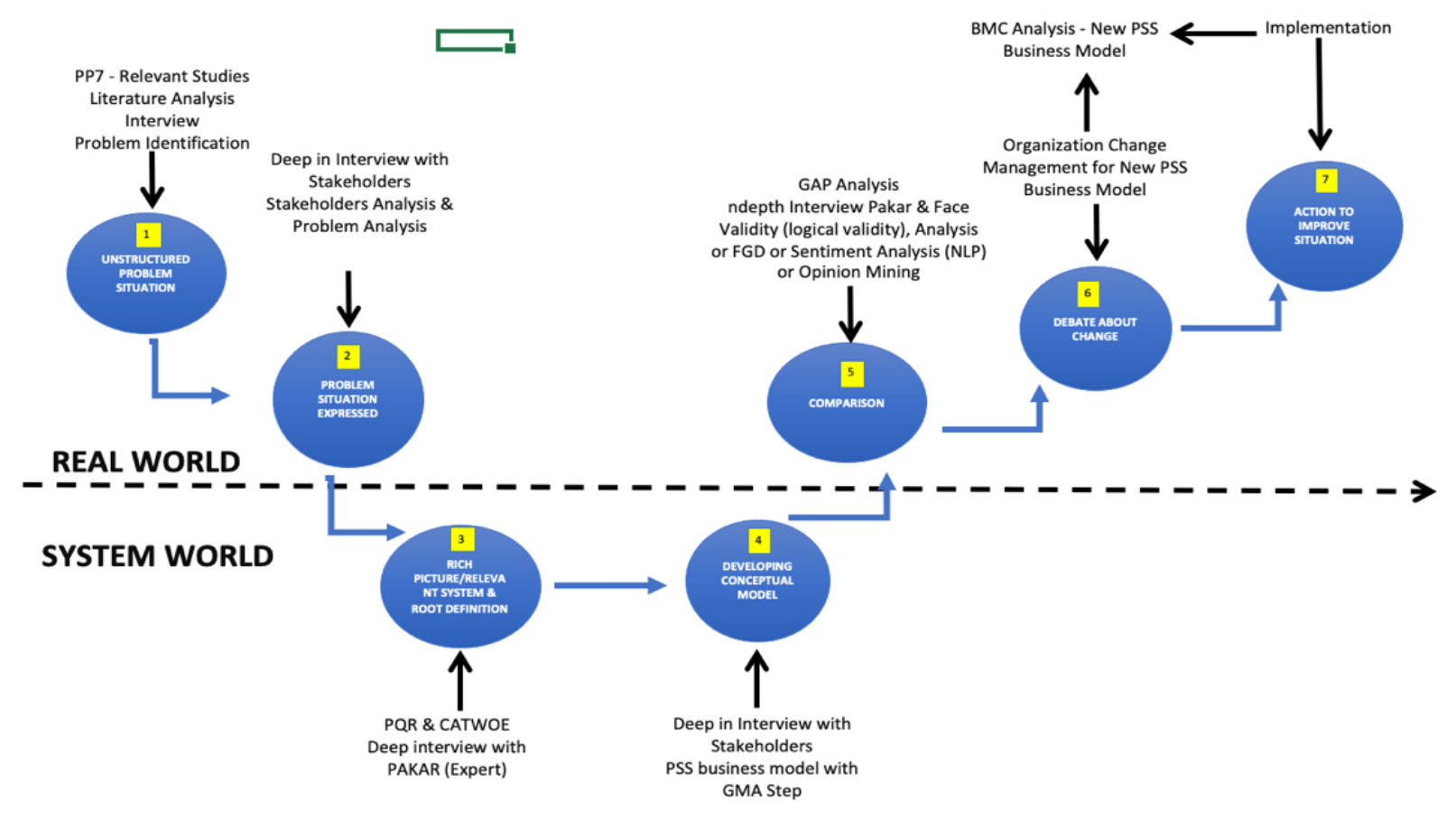

Figure 1. SSM Framework 


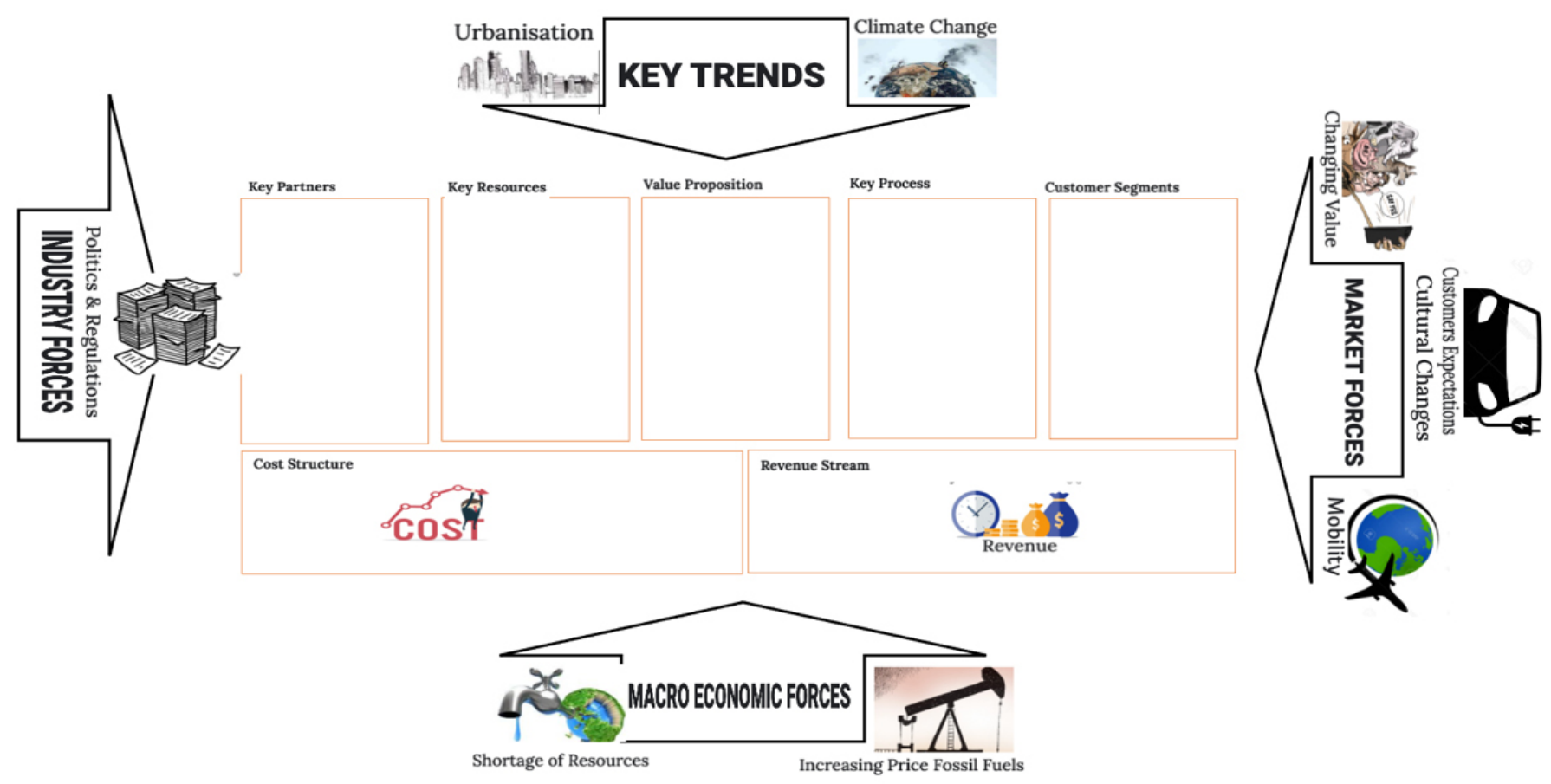

Figure 2. BMC analysis

The practical usage of PSS, the correct business model, must be recognized. The business model was a coherent depiction of how an organization directs its business with its products and services. It provided the basis for implementing strategies to help business managers change their business models and create customer value propositions. To offer services effectively, ESCOs should drastically change how they work and develop the capacity to plan and convey services instead of products and grow new knowledge, traditional standards, measurements, and incentives. Hence, to find the alternative business model creation, the authors used GMA and BMC (Figure 3).

\section{RESULTS}

In the energy-saving industry, price competition has been a previously considered aspect. Business practices largely depend on the Price required to be applied to provide the transaction's value directly. Since Price has repeatedly proven that it has the power to influence economic activity, companies from various industries rely heavily on these particular variables and facilitate their capabilities around them.

The current energy-saving market and industrial conditions themselves are challenging to control.
While the companies are busy developing the perfect product, other aspects such as growth, competition, and competition in the market also affect its internal development. The findings in several kinds of literature, a combination of market conditions, companies, products, and consumers contributed to the hypercompetition (Heil and Helsen, 2001). Although some authors have discussed suggestions on coping with price competition, hyper-competition remains one of the most challenging issues to do in a scenario. Nevertheless, one interesting, important aspect comes from the conditions of hyper-competition collected and successfully lived. As companies launch in industries where prices heavily saturate the market, there was little chance their future development will be facilitated by the same products they previously offered customers. The new business model of Product System Service (PSS) was an excellent way to create new customer value under hyper-competition. Furthermore, it supports the companies to survive.

The energy-saving industry was complicated since there are many stakeholders, each with its objectives to be met. As mentioned before, this paper used Checkland's Soft Systems Methodology (SSM) to illustrate current practices, analyze the problem and Identify stakeholders and their relationships. This paper identified a fundamental driving economic interest for each stakeholder. 


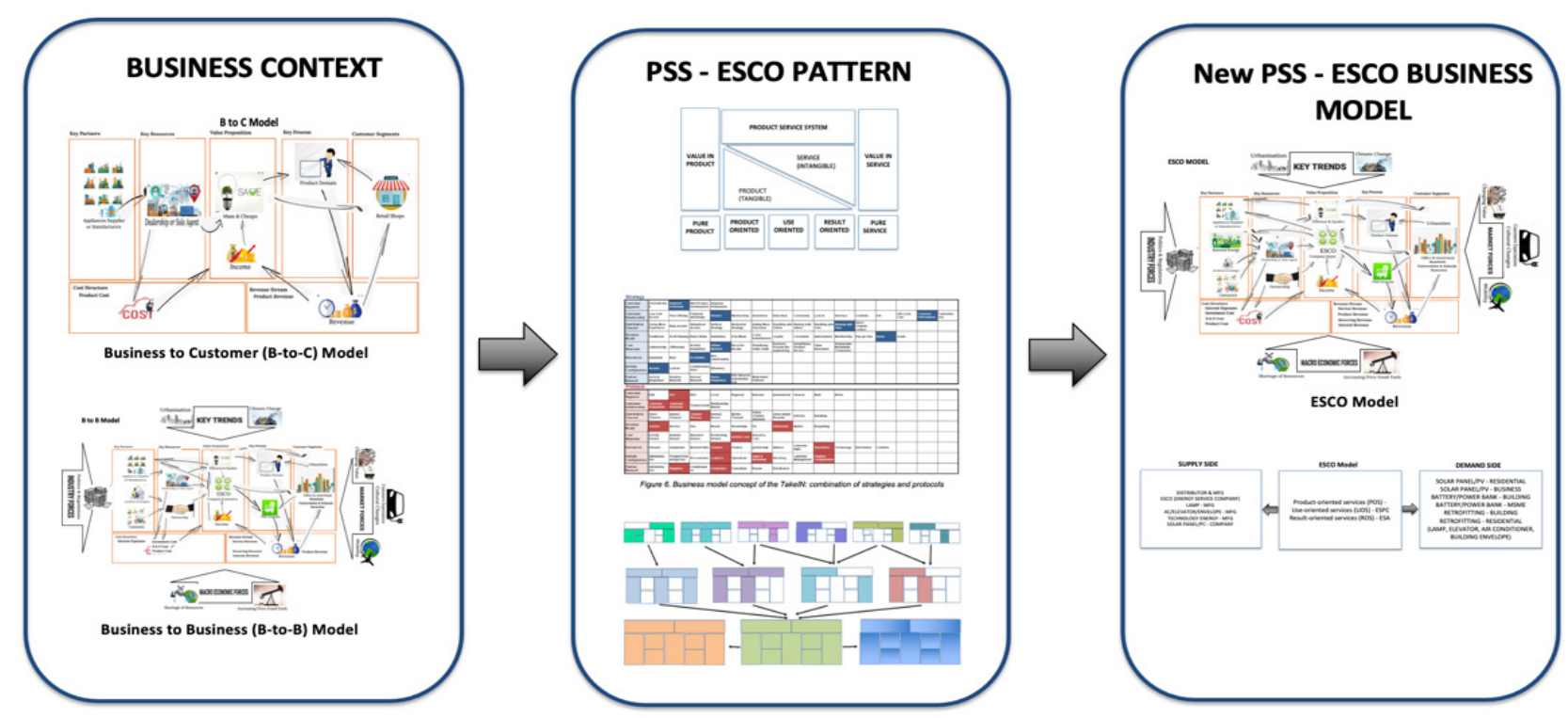

Figure 3. General morphological analysis framework

\section{Stakeholder Analysis}

The customer was a primary stakeholder in the energy efficiency market. The owner's interest was to maximize the value of a property (for profit or gain). The property owner was the primary stakeholder. Second, building occupant - the building occupant's primary economic concern was to mitigate energy costs, and the non financial objective was to reduce the "hazard factor" of the occupant. The occupant was a crucial element because their actions dictate the degree of electricity consumption. Energy consumption was a key factor affecting a building retrofit's performance and hence its profitability.

The occupants play a crucial role in determining energy efficiency choices, especially at an early stage, i.e., initial intent or set-up phase (Liang et al. 2014). Generally, only owners and occupants are involved in this case, suggesting provisional retrofit plans and exchanging retrofitting ideas. The vital role of stakeholders in energy management can be understood naturally and effectively, whereas occupants' role was still understated (Karvonen, 2013). Vandermerwe and Rada (1988)) suggested that the occupiers' impact makes retrofitting more complicated and riskier than new buildings because occupiers need to collaborate and engage in an ongoing retrofit (Miller and Buys, 2008).

In the future, occupiers' satisfaction can directly affect the occupancy rate, rent, and owner reputation. Besides economic influence, the occupiers' actions are significant energy consumption determinants (Azar and Menassa, 2012, 2014). The occupiers would influence the difference in energy consumption by up to 100 percent through different activities, such as ventilation patterns, behavior indoor temperature setting, and afterhour lighting usage (Ürge-Vorsatz, Novikova, Köppel, and Boza-Kiss, 2009). Many owners and tenants are preparing to carry out energy efficiency, but most of them are stopped at the beginning because it was challenging to find consensus.

Bank or Financial Institution was another essential stakeholder in the retrofit market. Banks want to see stable and predictable cash flows. They are not technical specialists in energy efficiency and need to have a track record of energy efficiency to be confident with the retrofit asset's value-added energy savings and to lend against it. Next was PT. PLN as energy providers and energy distributors. PT. PLN was highly regulated, yet, in particular, energy providers are trying to sell more electricity and produce it at a lower cost. The energy providers' economic interests may seem to be the most critical factor in the customers' dynamics involved in energy efficiency.

Other main stakeholders are Energy Saving Companies (ESCO) and Government. The primary economic interest of the ESCO was to optimize the benefit of energy efficiency investment. Some ESCOs may have an effort to establish a longer-term collaboration with the property owner or occupant to provide energy conservation, potentially further reducing the $\mathrm{CO} 2$ 
emissions of their customers. On the other hand, the government's primary economic objective was to find cost-effective ways to minimize its national greenhouse emissions, boost energy stability, increase jobs, and overall economic success and well-being. Energy conservation was an ideal way for the government to accomplish all of these targets.

Finally, General contractors and architects must be involved in the building process as soon as possible. Define the Owner's Project Specifications clearly and maintain an awareness of the 'green' design basis and sustainability criteria. Government officials may also be called upon to clear the confusion. Critical tasks need to be identified and assigned at each project phase, notably during design, construction, and inspection.

\section{GMA}

Furthermore, our finding in Checkland's SSM was an alternative business model creation. Based on GMA, we developed a conceptual-based system to support a new PSS business model creation. This alternative and conceptual-based PSS business model creation would be examined and how this alternative and conceptualbased PSS was different from the actual business case-based model. A GMA methodological table had been developed to create a wide range of business model options (Table 2). It consisted of a collection of empirical business patterns that display general aspects of business models' development, i.e., product or core competencies, consumer search, market research, supply chain creation, and cost or income prediction.

Table 1. Morphological Matrix

\begin{tabular}{|c|c|c|c|c|c|c|c|c|c|}
\hline $\mathrm{BMC}$ & $\begin{array}{l}\text { Customer } \\
\text { Segments }\end{array}$ & $\begin{array}{l}\text { Customer } \\
\text { Relation- } \\
\text { ships }\end{array}$ & $\begin{array}{l}\text { Distribution } \\
\text { Channel }\end{array}$ & $\begin{array}{l}\text { Revenue } \\
\text { Stream }\end{array}$ & $\begin{array}{l}\text { Key } \\
\text { Resources }\end{array}$ & $\begin{array}{l}\text { Key } \\
\text { Activities }\end{array}$ & $\begin{array}{l}\text { Key } \\
\text { Partner }\end{array}$ & $\begin{array}{l}\text { Cost } \\
\text { Structure }\end{array}$ & $\begin{array}{l}\text { Value } \\
\text { Proposition }\end{array}$ \\
\hline \multirow{11}{*}{ 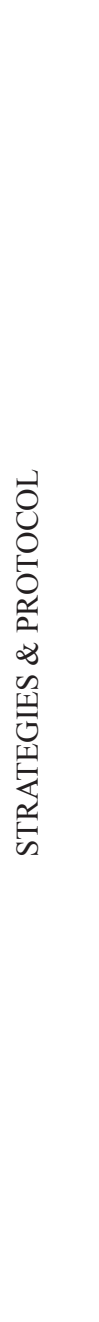 } & B2B & $\begin{array}{l}\text { Customer } \\
\text { Acquisition }\end{array}$ & $\begin{array}{l}\text { Experience } \\
\text { Shop }\end{array}$ & Product & Humans & Add service & $\begin{array}{l}\text { Adminis- } \\
\text { tration }\end{array}$ & $\begin{array}{l}\text { Activity } \\
\text { driver }\end{array}$ & $\begin{array}{l}\text { Repaired, } \\
\text { refurbished, } \\
\text { remanu- } \\
\text { factured, } \\
\text { or recycles } \\
\text { product }\end{array}$ \\
\hline & $\mathrm{B} 2 \mathrm{C}$ & $\begin{array}{l}\text { Customer } \\
\text { retention }\end{array}$ & Shop in shop & Service & Equipment & $\begin{array}{l}\text { Service pro- } \\
\text { ductization }\end{array}$ & Suppliers & $\begin{array}{l}\text { Industry } \\
\text { drivers }\end{array}$ & $\begin{array}{l}\text { Long-lasting } \\
\text { products }\end{array}$ \\
\hline & $\mathrm{B} 2 \mathrm{G}$ & $\begin{array}{l}\text { Transac- } \\
\text { tional }\end{array}$ & Delivery & $\begin{array}{l}\text { Pay per } \\
\text { unit }\end{array}$ & $\begin{array}{l}\text { Network } \\
\text { Infrastruc- } \\
\text { ture }\end{array}$ & $\begin{array}{l}\text { Standardiza- } \\
\text { tion }\end{array}$ & $\begin{array}{l}\text { Comple- } \\
\text { ment }\end{array}$ & $\begin{array}{l}\text { Resources } \\
\text { driver }\end{array}$ & $\begin{array}{l}\text { Product/ } \\
\text { Service base } \\
\text { function }\end{array}$ \\
\hline & Local & $\begin{array}{l}\text { Relation- } \\
\text { ship-based }\end{array}$ & Sales Person & $\begin{array}{l}\text { Subscrip- } \\
\text { tion }\end{array}$ & Channel & $\begin{array}{l}\text { Economies } \\
\text { of scale }\end{array}$ & $\begin{array}{l}\text { Competi- } \\
\text { tors }\end{array}$ & $\begin{array}{l}\text { Positioning } \\
\text { drivers }\end{array}$ & $\begin{array}{l}\text { Mainte- } \\
\text { nance, } \\
\text { repair, } \\
\text { control }\end{array}$ \\
\hline & Regional & $\begin{array}{l}\text { Customer } \\
\text { participa- } \\
\text { tion }\end{array}$ & $\begin{array}{l}\text { Road Shop } \\
\text { (Both) }\end{array}$ & $\begin{array}{l}\text { Razor } \\
\text { Blade }\end{array}$ & Finance & $\begin{array}{l}\text { Economies } \\
\text { of scope }\end{array}$ & $\begin{array}{l}\text { Consul- } \\
\text { tants }\end{array}$ & Activity cost & $\begin{array}{l}\text { product- } \\
\text { service } \\
\text { based result }\end{array}$ \\
\hline & $\begin{array}{l}\text { Interna- } \\
\text { tional }\end{array}$ & Reward & $\begin{array}{l}\text { Web } \\
\text { (mobile) }\end{array}$ & Ad-based & Partnership & No frill & Buyers & $\begin{array}{l}\text { Resource } \\
\text { cost }\end{array}$ & upgrading \\
\hline & General & Upgrade & $\begin{array}{l}\text { Indirect } \\
\text { Channel }\end{array}$ & Freemium & Reputation & Self-service & $\begin{array}{l}\text { Distribu- } \\
\text { tors }\end{array}$ & - & $\begin{array}{l}\text { auxiliary } \\
\text { services }\end{array}$ \\
\hline & $\begin{array}{l}\text { Multi Mar- } \\
\text { ket }\end{array}$ & $\begin{array}{l}\text { Blockbuster } \\
\text { Marketing }\end{array}$ & $\begin{array}{l}\text { Direct } \\
\text { Channel }\end{array}$ & Donation & $\begin{array}{l}\text { Customer } \\
\text { base }\end{array}$ & Peer to peer & $\begin{array}{l}\text { R \& D } \\
\text { Collabora- } \\
\text { tion }\end{array}$ & - & - \\
\hline & Niche & $\begin{array}{l}\text { Life-cycle } \\
\text { care }\end{array}$ & $\begin{array}{l}\text { Channel } \\
\text { Sharing }\end{array}$ & $\begin{array}{l}\text { Commis- } \\
\text { sion }\end{array}$ & $\begin{array}{l}\text { Crowd- } \\
\text { sourcing }\end{array}$ & - & $\begin{array}{l}\text { Design } \\
\text { Collabora- } \\
\text { tion }\end{array}$ & - & - \\
\hline & - & $\begin{array}{l}\text { Customiza- } \\
\text { tion }\end{array}$ & Bundling & Loyalty & $\begin{array}{l}\text { Open- } \\
\text { source }\end{array}$ & - & $\begin{array}{l}\text { Joint Dis- } \\
\text { tribution }\end{array}$ & - & - \\
\hline & - & Education & $\begin{array}{l}\text { Valued add- } \\
\text { ed reseller }\end{array}$ & $\begin{array}{l}\text { Subsid- } \\
\text { iary }\end{array}$ & $\begin{array}{l}\text { Outsourc- } \\
\text { ing }\end{array}$ & - & $\begin{array}{l}\text { Shared In- } \\
\text { vestment }\end{array}$ & - & - \\
\hline
\end{tabular}


GMA was used as a starting point for problem structuring because it tackled customer segments, customer relationships, distribution channel, revenue stream, essential resources, key activities, key partner, cost structure, and value proposition. Several empirical pieces of research have used GMA within the corporate sector to analyze health care systems planning. Proctor (1991) used Creativity in the management field (1991). Ritchey (1998) used GMA as a policy analysis tool. In research strategies for Economic Development, Duczynski (2004) used Indigenous People in Australia. Moreover, (Alvarez and Ritchey (2015) studied the Strategies for an Extended Producer Responsibility (EPR) system.

\section{BMC Analysis}

As been explain in Checkland's Soft Systems Methodology (SSM) Step 6 above - BMC has been employed for the alternative business model innovation. Empirical findings that $90 \%$ of all business model developments were reabsorption of existing business model norms. The organization would use a business model that has already been confirmed to be profitable for other business sectors. As a result, the organization wants to use the business model patterns to effectively incorporate innovation (Remane et al. 2017).

The most appropriate revenue stream in the energy efficiency industry was the PSS business model that applies the business model as 'usage oriented and 'result-oriented. Revenue streams were generated using specific services. Initially, the result-based compensation was derived from performance-based contracting of public-private partnerships (PPPs) in the mid-twentieth century. Over time, it evolves and found its way. BASF Coatings was the first company to use the 'cost per product' revenue stream since the late 1990s. Xerox, an American maker of printers and photocopiers, was providing results-based payments. It evolved once again as Roll Royce implements this model; the program's name was Power by Meter. The Final, the alternative propose business model, can be drawn, as Figure 5.

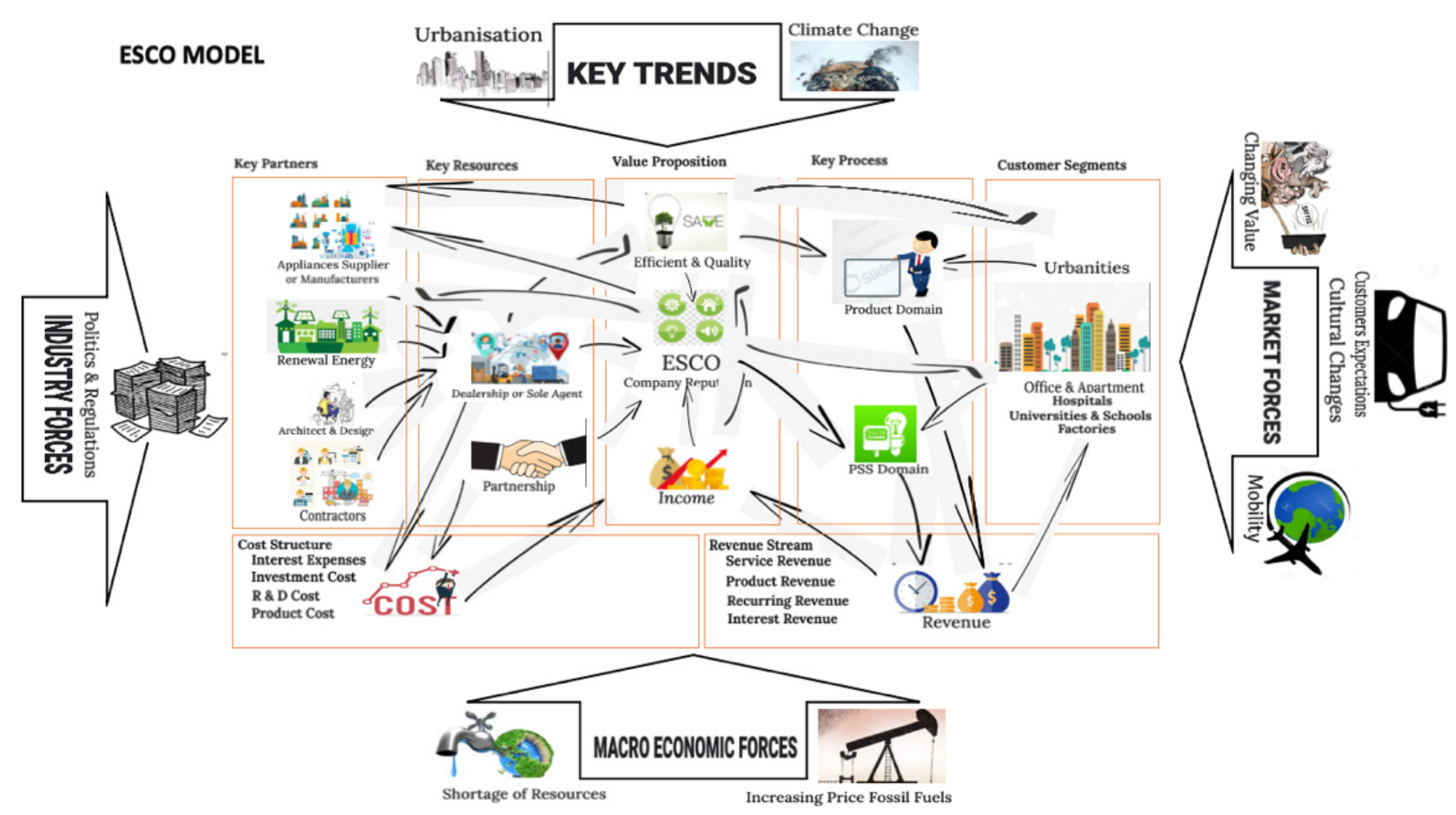

Figure 5. New PSS ESCO Business Model 


\section{Managerial Implications}

The topics of PSS, ESCO, electricity consumption, and energy efficiency phenomenon are not for everyone. The phenomenon, nevertheless, will always be entangled with the concept of macro-economy. As the idea is much more subtle in execution, the framework model on identifying the new PSS business model may benefit critical stakeholders, including regulators, investors, and companies. There is a possibility that energy conflicts might happen in the future. Hence, the article's applicability to management practice is 'High Level of Management Practices.' At the same time, it has been said that energy regulation, especially the energy-efficiency industry in Indonesia, is currently undergoing some drastic changes. It cannot be denied that the key stakeholders such as regulators, investors, and companies remain a strong influence when a decision has to be made. While it is interesting to see how key stakeholders, including regulators, investors, and companies, deal with energy consumptions, energysaving, and renewal energy. Most of the government is now forced to step into identifying and prevent climate change. However, this paper framework model was developed in the context of Indonesia's energy practices. However, in the International context, the Authors think this paper directly influences global policies in energy efficiency, especially in emerging countries. Based on this argument, the article's practicality to the Indonesian market is High.

\section{CONCLUSIONS AND RECOMMENDATIONS}

\section{Conclusions}

Furthermore, our finding in Checkland's SSM was an alternative business model creation. Based on GMA and BMC, we developed a conceptual-based system to support a new PSS business model creation. This conceptual-based PSS model help MWS in the form of the "ESCO model" with their capitals in Indonesia. The PSS business model creation would be implemented and how this alternative and conceptual-based PSS was different from the actual business case-based model. This study responds to the lack of research addressing the PSS's business model creation by developing the model using SSM, GMA, and BMC approaches. The identification and description of the MWS' PSS business model's specific features were derived from an existing and popular business model pattern. The business model pattern and classifications can be applied as a design pattern in designing conceptual business models.

It is an essential precondition for Indonesia to have a good energy efficiency program. These comprehensive plans are necessary to catch up with other countries, fill the gap in the lack of energy demands, value energy efficiency, encourage retrofit, and reduce energy consumption and greenhouse gas emissions. Again, these prerequisites would determine whether Indonesia's government measures up to date are sufficient. The Indonesian government is supposedly aware of the situation and has started setting energy-saving targets for 2025 and 2050. This energy efficiency awareness can solve this energy scarcity, filling the supply-demand gap and fighting climate change on carbon emissions tandemly.

The authors believe, by adopting the new PSS business model. MWS was ready to unleash new business opportunities in energy saving in Indonesia. Beyond the increasing demand for energy and limited supply, there is a vast, untapped opportunity for energy saving in Indonesia's various sectors. This study helps understand how market barriers are the main problem and daunt the ESCO's energy efficiency environment. Understanding the nature of the energy efficiency market and the consequences, its new PSS business model will benefit all the stakeholders. The energy efficiency retrofitting through ESCO is technically feasible and economically viable in Indonesia. New technologies in energy efficiency and appliances are already in the marketplace. Thus, this study is expected to give some benefits as follows: 1) Self-ESCO practices and retrofit financing are relatively new in Indonesia; therefore, this study is likely to contribute to the ESCO practices, 2) The research is expected to be one of the sources of information about the factors that influence the desire to conduct a retrofit transaction in Indonesia, and 3) In the industrial field/practitioner, companies have rooms to reduce utility costs and run competitively by utilizing retrofit practices.

\section{Recommendations}

The adoption of energy efficiency in the building industry has become of great importance, given the links between energy use and global environmental change. The literature on innovation theory can provide insight into the problem of improving the adoption of energy efficiency. There are vital aspects to promoting the 
technology of energy efficiency more effectively, look into enhancing the rate of adoption of energy-efficient. Several strategies encourage innovation in ESCO, i.e., incentive programs, building rating programs, and financing opportunities. The potential benefits are crystal clear to the environment - the author analyses building energy efficiency under the case study and literature. Meantime, the author did not explore or discuss the renewal energy, supply-side management, and new energy-efficiency appliances (green products). This study also did not explore business potential in household residential through vast opportunities, which was the most important thing done by any ESCO in the developed countries. Therefore, the following authors need to understand the obstacles in promoting the development and adoption of energy efficiency practices in household energy efficiency and ESCO in Indonesia. The following papers should investigate the behavior of individuals and organizations. The author believes many possible subjects need to be explored and included in this study, which means there is room for future researchers.

\section{REFERENCES}

Abdullah MA, Rönnbäck AÖ, Sandström GÖ. 2010. Building Networks for Delivering Integrated Product-Service Offerings (IPSOs). In The 2nd CIRP IPS2 Conference. hlm 499-506.

Alvarez A, Ritchey T. 2015. Applications of general morphological analysis-from engineering design to policy analysis. Acta Morphological Generalis $4(1): 1-40$.

Ang GCJ, Baines T, Lighfoot H. 2010. A Methodology for Adopting Product Service Systems as a Competitive Strategy for Manufacturer. In CIRP IPS2 Conference. hlm 489-496.

Azar E, Menassa CC. 2012. A comprehensive analysis of the impact of occupancy parameters in energy simulation of office buildings. Energy and Buildings 55:841-853.https://doi.org/10.1016/j. enbuild.2012.10.002

Azar E, Menassa CC. 2014. A comprehensive framework to quantify energy savings potential from improved operations of commercial building stocks. Energy Policy 67:459-472. https://doi.org/10.1016/j.enpol.2013.12.031

Baines TS, Lightfoot HW, Benedettini O, Kay JM. 2009. The servitization of manufacturing: A review of literature and reflection on future challenges. Journal of Manufacturing Technology Management 20(5):547-567.https:// doi.org/10.1108/17410380910960984

Duczynski G. 2004. Systems approaches to economic development for indigenous people: A case study of the Noongar Aboriginals of Australia. Futures 36:869-888.https://doi.org/10.1016/j. futures.2004.01.001

Goedkoop MJ, van Halen CJG, te Riele HRM, Rommens PJM. 1999. Product Service systems, Ecological and Economic Basics.

Karvonen A. 2013. Towards systemic domestic retrofit: A social practices approach. Building Research and Information 41(5):563-574.https://doi.org/1 $0.1080 / 09613218.2013 .805298$

Liang C, Zhang R, Lu W. 2014. The optimal strategy of using BIM in construction. Management 995-1001.https://doi.org/10.1007/978-3-64235548-6_102

Miller E, Buys L. 2008. Retfofitting commercial office buildings for sustainability: tenants' perspectives. Journal of Property Investment and Finance 26(6): 552-561.https://doi. org/10.1108/14635780810908398

Osterwalder A, Pigneur Y. 2010. Business Model Generation: A Hits Book For Visionaries, Game Changers, I-Challengers. New Jersey: John Wiley and Sons.

Pawar KS, Beltagui A, Riedel JCKH. 2009. The PSO triangle: Designing product, service and organisation to create value. International Journal of Operations and Production Management 29(5):468-493. https://doi. org/10.1108/01443570910953595

Peraturan Pemerintah Republik Indonesia. 2009. Peraturan Pemerintah Republik Indonesia Nomor 70 Tahun 2009 Tentang Konservasi Energi.

Proctor RA. 1991. The importance of creativity in the management field. British Journal of Management 2: 223-230.https://doi.org/10.1111/ j.1467-8551.1991.tb00028.x

Remane G, Hanelt A, Tesch JF, Kolbe LM. 2017. The business model pattern database - a tool for systematic business model innovation. International Journal of Innovation Management 21(1). https://doi.org/10.1142/ S1363919617500049

Ritchey T. 1998. General Morphological Analysis: A general method for non-quantified modelling. In 16th Euro Conference on Operational Analysis. Brussels. 
Ronja H, Pigosso DCA, McAloone TC. 2017. Product/ service-system origins and trajectories: A Systematic literature review of pss definitions and their characteristics. Procedia CIRP 64:157-162. https://doi.org/10.1016/j.procir.2017.03.053

Sakao T, Lindahl M. 2009. Introduction to Product/ Service-System Design. Berlin: Springer Science and Business Media.https://doi.org/10.1007/9781-84882-909-1
Ürge-Vorsatz D, Novikova A, Köppel S, Boza-Kiss B. 2009. Bottom-up assessment of potentials and costs of $\mathrm{CO} 2$ emission mitigation in the buildings sector: Insights into the missing elements. Energy Efficiency 2:293-316. https://doi.org/10.1007/ s12053-009-9051-0

Vandermerwe S, Rada J. 1988. Servitization of business: Adding value by adding services. European Management Journal 6(4):314-327. https://doi. org/10.1016/0263-2373(88)90033-3 